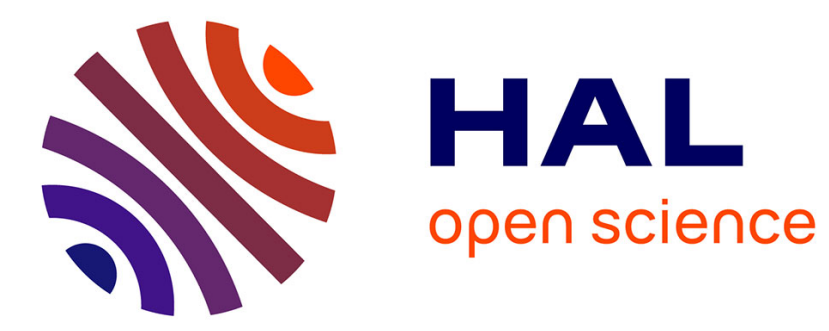

\title{
Evaluating flash-flood warnings at ungauged locations using post-event surveys: a case study with the AIGA warning system
}

\author{
P. Javelle, J. Demargne, D. Defrance, J. Pansu, P. Arnaud
}

\section{To cite this version:}

P. Javelle, J. Demargne, D. Defrance, J. Pansu, P. Arnaud. Evaluating flash-flood warnings at ungauged locations using post-event surveys: a case study with the AIGA warning system. Hydrological Sciences Journal, 2014, 59 (7), pp.1390-1402. 10.1080/02626667.2014.923970 hal-01470408

\author{
HAL Id: hal-01470408 \\ https://hal.science/hal-01470408
}

Submitted on 17 Feb 2017

HAL is a multi-disciplinary open access archive for the deposit and dissemination of scientific research documents, whether they are published or not. The documents may come from teaching and research institutions in France or abroad, or from public or private research centers.
L'archive ouverte pluridisciplinaire HAL, est destinée au dépôt et à la diffusion de documents scientifiques de niveau recherche, publiés ou non, émanant des établissements d'enseignement et de recherche français ou étrangers, des laboratoires publics ou privés. 


\title{
Evaluating flash flood warnings at ungauged locations using post-event surveys: a case study with the AIGA warning system
}

\author{
PIERRE JAVELLE ${ }^{1}$, JULIE DEMARGNE ${ }^{2}$, DIMITRI DEFRANCE ${ }^{1}$, JEAN \\ PANSU $^{3}$, PATRICK ARNAUD ${ }^{1}$ \\ 1 Irstea (formerly Cemagref), Centre Régional d'Aix-en-Provence, CS 40061, 13182 AIX EN PROVENCE Cedex 5, \\ France \\ pierre.javelle@irstea.fr \\ 2 HYDRIS Hydrologie, 5 Av.du Grand Chêne, 34270 Saint Mathieu de Tréviers, France \\ 3 Météo-France, Direction Interrégionale Sud-Est, 2, Bd Chateau-Double, 13098 Aix-en-Provence cedex 02, \\ France
}

To cite this article: Pierre Javelle, Julie Demargne, Dimitri Defrance, Jean Pansu \& Patrick Arnaud (2014) Evaluating flash-flood warnings at ungauged locations using post-event surveys: a case study with the AIGA warning system, Hydrological Sciences Journal, 59:7, 1390-1402, DOI: 10.1080/02626667.2014.923970

\begin{abstract}
This paper presents a comparison between real-time discharges calculated by a flash flood warning system (AIGA) and post-event flood peak estimates. The studied event occurred on June $15^{\text {th }}$ and $16^{\text {th }}, 2010$, at the Argens catchment located in the South of France. Real-time flood warnings were provided by the AIGA warning system, which is based on a simple distributed hydrological model run at a $1-\mathrm{km}^{2}$ resolution using radar rainfall information. The timing of the warnings (updated every 15 minutes) was compared to the observed flood impacts. Furthermore, 'consolidated' flood peaks estimated by an intensive post-event survey were used to evaluate the AIGA-estimated peak discharges. Results indicated that the AIGA warnings clearly identified the most affected areas. However, the effective lead-time of the event detection was short, especially for fast response catchments, due to the fact that the current method does not take into account any rainfall forecast. The flood peak analysis showed a relatively good correspondence between AIGA- and fieldestimated peak values, although some differences were due to the rainfall underestimation by the radar and rainfall-runoff model limitations.
\end{abstract}

\section{Key word}

Ungauged, flash flood, warning system, evaluation, post-event survey

\section{INTRODUCTION}

Flash floods are typically caused by torrential rainfall and efficient runoff production due to a variety of hydrologic characteristics (such as antecedent soil moisture conditions, soil type and depth, terrain slope, land use and vegetation), which leads to short time lags between the rainfall occurrence and peak discharge. These extreme events tend to occur at very small spatial and temporal scales (generally affecting areas up to a few hundred square kilometres, from minutes to a few hours) and to evolve extremely rapidly (Borga et al., 2007). They are difficult to observe and predict at the scales of interest, especially with sparse hydrometric networks (potentially malfunctioning during extreme flood events). In terms of human impacts, Ruin et al (2008) showed that during the September 2002 flood event in the South of France most damages occurred in headwater basins (ca. $10 \mathrm{~km}^{2}$ ), which reacted 
repeatedly across the entire storm duration. For these reasons, flash flood warning systems face a very challenging task for providing timely and effective warnings for improved communities' preparedness about flood risk (Creutin and Borga, 2003).

However, warning systems have recently benefitted from advances in rainfall estimations from radar, satellite, and gauged data, precipitation forecasts produced by numerical weather prediction (NWP) models and extrapolations from radar or satellite measurements with increased forecast horizons, remotely-sensed catchment data (such as near-surface soil moisture, snow cover) with improved temporal and spatial accuracy, as well as progress in hydrologic modelling (Hapuarachchi et al. 2011). However, assessing how flash flood warning systems perform represents a major challenge since traditional calibration and validation procedures can only be made at gauged stations, which are in a limited number and generally not representative of all 'target' catchments in flash flood affected areas. In this context of rare data, systematic post-event collection of all possible information related to damages, timing, peak discharge, and flow velocity, is of great importance (Ruin et al., 2008, Gourley et al., 2013). It helps to replace a particular event in a broader perspective (Gaume et al., 2009). It also provides useful data to evaluate the performance of flash flood warning systems in place.

\section{- Flash flood warning systems}

The most common approach for an early indication of upcoming potential flash flooding consists in comparing the latest precipitation observations and forecasts to pre-defined reference thresholds for warnings. Alfieri et al (2012a) provided a comprehensive review of operational early warning systems in Europe, emphasizing the challenges of detecting local severe precipitation below the resolution of most available NWP models and accounting for the forecast uncertainty. For example, the European Index based on simulated Climatology (EPIC) is estimated at a $1-\mathrm{km}^{2}$ resolution from meteorological ensemble forecasts available at coarser resolution and identifies catchments at risk. The Probabilistic Flash Flood Guidance System is then activated at the regional scale using higher-resolution observed and nowcasted rainfall fields (Alfieri et al. 2012a). At national level, Météo-France developed a heavy rainfall warning system, called APIC (Carriere et al, 2013), based on the comparison of cumulated rainfall estimates (from radar fields and gauge measurements as described below) with reference rainfall quantiles (maximum rainfall in 1- to 72-hr periods) for various return periods. The rainfall quantiles are derived by a frequency analysis method called SHYREG using a regionalised stochastic rainfall generator (Arnaud et al, 2008). The APIC automated warning system is limited to spatial areas with high quality radar-gauge rainfall estimates and does not account for hydrological conditions and basin response.

Therefore flash flood warning systems for ungauged basins could also include hydrologic and hydraulic models, either in a lumped or distributed modelling approach, to produce flow forecasts, ideally on a high spatial and temporal resolution similar to the flash flood processes, e.g., from $1 \mathrm{~km}^{2}$ to a few $\mathrm{km}^{2}$ and on the order of 1 to 10 minutes. In reality, such high-resolution systems are still in a research and development phase and most operational flash flood forecasting systems use lumped hydrologic models on a much coarser spatial and temporal resolution. For example, in the US National Weather Service (NWS), the operational Flash Flood Guidance (FFG) method for the Eastern US region provides flood warnings by running in real- 
time the hydrologic forecasting system with what-if rainfall scenarios to estimate the average rainfall (over a specified area and for a given time duration) that will initiate flooding on small streams (Georgakakos, 2006). The FFG values, expressed in rainfall units for a specified duration, take into account the hydrologic initial and future conditions. NWS forecasters compare, in real-time, observed and future rainfall accumulations to FFG estimates to decide whether to issue a flood warning. However, such FFG estimates are derived from the lumped Sacramento Soil Moisture Accounting (SAC-SMA) model, which is usually calibrated on basins larger than 250 $\mathrm{km}^{2}$ and run on a 1-hr to 6-hr time step. To address such scale mismatch issues, an alternative solution is to use a high-resolution distributed hydrologic model with $a$ priori parameters. In the approach presented by Reed et al (2007) and called Distributed Hydrologic Model - Threshold Frequency (DHM-TF), the distributed hydrologic model (such as the HL-RDHM based on the SAC-SMA model) is used to produce flow forecast peaks, which are statistically processed to estimate corresponding return periods based on multiple-year flow peak simulations. By comparing, for each grid cell, the return periods estimated (in real-time) by the distributed model with critical frequency thresholds derived locally, forecasters can decide whether to issue flood warnings.

In Europe, the operational European Flood Alert System (EFAS) is an example of a similar operational flood warning system based on a distributed hydrologic modelling approach (Ramos et al, 2007, Thielen et al, 2009, Bartholmes et al, 2009). Originally developed for large trans-border catchments, some promising results were obtained on small watersheds prone to flash floods by Younis et al (2008) on French Mediterranean basins and more recently by Alfieri et al (2012b) in Switzerland. In the latter study, streamflow ensembles are produced from COSMOLEPS meteorological ensembles at finer spatio-temporal scales for basins prone to flash flooding. Flow ensembles are then compared to coherent warning thresholds estimated by running long-term reforecast record through the same hydrological model. However the authors emphasized that the space-time resolution of precipitation forecasts is often too coarse to describe the observed variability of severe storms, leading to flow underestimation especially in small catchments (Alfieri et al 2012). In the United Kingdom, an operational system has also been developed based on the distributed Grid to Grid model (G2G) developed by the Centre for Ecology and Hydrology (Cole and Moore 2009).

In France, to address flash flood warning issues for small ungauged basins, Météo-France and Irstea (formerly Cemagref) have developed a discharge-threshold flood warning system called AIGA, which combines radar-gauge rainfall grids with a simplified distributed hydrologic model run every 15 minutes at a $1-\mathrm{km}^{2}$ resolution (Javelle et al, 2010). The AIGA system shares similarities with the DHM-TF distributed approach described by Reed et al. (2007) and the G2G approach (Cole and Moore 2009), even if the hydrologic models differ. However, AIGA produces, in realtime, peak discharge estimates along the river network (and not for grid cells), which are compared to regionalized flood frequency estimates. Warnings are provided on a river network map according to the AIGA-estimated return period of the ongoing event. This system alerts operational forecasters at the regional flood forecasting centres (SPC) and the national hydro-meteorological and flood forecasting centre (SCHAPI) when dangerous flash flood situations may be developing in ungauged basins. 
The evaluation of flash flood warning systems is essential for both the research and user communities. It enables them to identify their strengths and weaknesses, and to define targeted system improvements. It also provides forecasters with an objective level of confidence in their forecasts and alerts. Such performance evaluation should describe three main aspects of the warning system corresponding to the estimation of the event magnitude, its location, and its timing. However, the evaluation of a flash flood warning system for ungauged basins is inherently difficult due to the lack of hydrometeorological datasets and the small scales of the events. To address this issue, the evaluation could consider gauged basins as ungauged locations for model calibration and therefore use available hydrometeorological data for its evaluation. However, the small gauged basins used for calibration and validation are usually larger than the scale of the flash flood events and thus this evaluation approach tends to be performed on a coarser spatial scale.

As a complementary approach, the evaluation could also be performed on ungauged basins by using reports of the event impacts observed on the ground, as well as estimated flood peaks using high water marks and/or remotely sensed data, from which surface water extents can be estimated.

Regarding reports of ground impacts, the NWS maintains an archive of severe weather events reports, including flash floods, for the U.S. Reports are collected from official and trained spotters (including the NWS Weather Forecast Offices), as well as emergency management officials, businesses, insurance companies, the media and the general public. These reports are stored in the NWS Storm Data database archived by the US National Climatic Data Center; a detailed description of this database is available at www.ncdc.noaa.gov/oa/climate/sd/sdfaq.html. Gourley et al (2010) underlined one of the main limitations of such database for flash flood evaluation: no archiving of the no flooding reports in warned regions (which indicate false alarms) and no focus on missed events (flash flood events without any warning).

In order to better collect observations for evaluating flash flood warning systems, the NWS National Severe Storms Laboratory has led the Severe Hazards Analysis and Verification Experiment (SHAVE) (Ortega et al., 2009) project since 2006 as part of the NOAA Hazardous Weather Testbed (ewp.nssl.noaa.gov/projects/ shave/). The project uses an original data collection strategy to build a high temporal and spatial resolution observed database for mainly hail, wind, flash flood and tornado events via the real-time analysis of high-resolution radar data and on-going NWS warnings in geographic information systems. Such geospatial analysis enables surveyors to make verification telephone calls to individuals and companies in the immediate aftermath of a warned or reported storm. Gourley et al (2010) presented the collection strategy for potential flash flood events, which are described in terms of flooding location, flood impacts (e.g., on bridges, roads, properties), extent and depth of water (e.g. in comparison to cars, house windows), start and end times of the event, rescued people, and the approximate flood frequency estimated by respondents. Compared to the NWS Storm Data, the SHAVE reports are point-specific with a higher density, and contain additional information, such as no flooding reports.

Even if both observed flood databases (NWS Storm data, and SHAVE) do not provide a comprehensive identification of all flash flood events with accurate spatiotemporal description, they enabled Gourley et al (2012) to conduct a detailed comparison of the performances of FFG and recently developed gridded FFG (GFFG) 
used operationally in the NWS. Also Calianno et al (2013) used these databases to classify the impacts of flash floods in relation with socio-spatial attributes (such as land use and population density) and to evaluate whether flash flood forecasting tools (namely FFG, GFFG, and DHM-TF) could differentiate such categories of impacts. Also the authors gave specific recommendations on the data collection methodology to better describe the spatial and timing characteristics of the observed events and to account for errors in human reports. The NWS storm reports, the SHAVE survey responses, and the USGS streamflow measurements are now part of a US-wide unified database of flash flood observations, which is freely available and will be updated every year (Gourley et al 2013).

In Europe, examples of such systematic reporting and archiving for flash flood events and their impacts are limited so far. The HYdrometeorological Data Resources And Technologies for Effective flash flood forecasting (HYDRATE) project (www.hydrate.tesaf.unipd.it/) defined a common flash flood observation strategy and developed a European flash flood database with hydrometeorological observations and complementary information from post-event surveys all across Europe (Gaume et al. 2010). Also, as part of the Hydrological cycle in the Mediterranean Experiment (HyMeX) project (www.hymex.org), the "Task Team for Observation" that incorporates scientists from different European countries organizes post-event surveys after main flash floods, including witness interviews, indirect methods for flood peak estimation, and geomorphic analysis (e.g., mapping erosion and deposition, displaced volumes, induced destructions). In France, the RHYTMME project on hydrometeorological risks in mountainous and Mediterranean terrains (rhytmme.cemagref.fr/synopsis), led by Météo-France and Irstea, includes an evaluation of flash flood warning methods (e.g., AIGA) using post-event impacts observed on the ground and collected by different public services.

\section{- Case study event}

This paper aims to show the value of post-event surveys to better assess flash flood warnings at ungauged locations. The studied event occurred on June $15^{\text {th }}$ and $16^{\text {th }}$ 2010 on the Argens catchments, located in the South of France. Urbanized areas, especially around the town of Draguignan, were significantly affected by the flood, with a total of 25 casualties. The AIGA warning system was the only source of realtime information on the hydrological states of the impacted rivers as no river gauges could transmit information during the flood. Given the significant impact of this extreme event, an intensive post-event survey was conducted by various expert teams, from which flood peak values were estimated at different locations along the river network. Additionally to witness interviews describing the timing of the flood event and the induced damages, this dataset offers the opportunity to evaluate the flood warnings produced by the AIGA system.

The paper is organised as follows. It first describes the AIGA flash flood warning system, including its real-time radar quantitative precipitation estimation (QPE) input and its underlying distributed hydrologic model. Then, it presents the June $15^{\text {th }}$ and $16^{\text {th }} 2010$ flood event and the corresponding warnings that were issued. The third section presents post-event flood peak estimates and compares them to modelled discharges. 


\section{THE AIGA FLASH FLOOD WARNING SYSTEM}

Operational since 2005 in the Southern part of France, the AIGA system has been developed by Irstea and Météo-France with financial support from the French Ministry in charge of ecology. Run by Météo-France for the French Mediterranean region, it produces, every 15 minutes, a map of the river network with a colour chart indicating the range of the estimated return period of the ongoing flood event. As illustrated in Figure 1, AIGA is based on the comparison of real time estimated peak discharges with regionalized peak flow quantiles for various return periods. The main interest of this product is that it gives a real-time hydrological information at any point of the river network, while classical systems based on water-level monitoring inform about the situation only at the teletransmitted stations.

The following paragraphs describe the radar-rainfall data taken into account by AIGA and the associated hydrological modelling.

\section{The French radar quantitative precipitation estimation (QPE)}

The current French radar product of Météo-France, called PANTHERE, combines reflectivity data from 24 radars ( $\mathrm{C}$ and $\mathrm{S}$-band) and ground measurements from teletransmitted rain gauges. The final product provides every 5 minutes a national map of cumulated rainfall with a $1-\mathrm{km}^{2}$ resolution. The three following main steps are involved to obtain the final radar product.

1. First, a QPE is calculated from the reflectivity measurement for each radar of the network. This estimation includes different corrections based on radar data only (Tabary, 2007) for ground clutter, partial beam blocking, VPR effects, and advection. At the end of this stage, a quality index is also calculated at each pixel and time step, informing about the correction level.

2. Then, the radar QPE is corrected using rain gauges. A corrected factor (CC) is computed using radar and rain gauges of the past hours in "good radar quality" areas (up to $\sim 100 \mathrm{~km}$ range distance from the radar in flat ground). CC is updated each hour and applied to the 5-minute radar QPE of the current hour. It is calculated as follows (Emmanuel et al., 2012, Champeaux et al., 2012):

$$
C C_{H}=\frac{\sum_{i=H-M}^{i=H} w_{i} P_{i}+C_{\text {Rap }}}{\sum_{i=H-M}^{i=H} w_{i} R_{i}+\frac{C_{\text {Rap }}}{F C_{\text {HYDRAM }}}}
$$

with:

$P_{i}$, rain gauge hourly accumulation

$R_{i}$, radar hourly accumulation

$F C_{\text {HYDRAM }}$, monthly calibration factor

$C_{\text {Rap }}$, weight controlling the speed at which $\mathrm{CC}$ deviates from the $\mathrm{FC}_{\mathrm{HYDRAM}}$ monthly calibration factor

$M$, memory of the algorithm ( $\mathrm{M}=40$ hours)

$w_{i}$, weighting factor $\left(w_{i}=2^{-\frac{i}{T}}\right.$, with $\mathrm{T}=4$ hours $)$ 
3. Finally, all individual radar corrected QPEs are merged into a unique QPE Cartesian grid covering the whole French territory with a $1 \mathrm{~km}^{2}$ spatial resolution. The final QPE product is obtained using a weighted sum of the individuals QPEs with their quality indexes as weighting factors (Tabary, 2007).

\subsection{Hydrological modelling}

The hydrological modelling is carried out by a simple distributed model called GRD. It combines the following steps:

- Estimating a daily soil moisture index

First, a soil moisture index is estimated for each $1-\mathrm{km}^{2}$ pixel at a daily time step using a soil moisture accounting model (SMA) derived from the GR4J model (Perrin et al, 2003). It is composed by a unique store with a maximal capacity equal to $A_{S M A}$. If rainfall is greater than the evapotranspiration, then a quantity $P S$ fills the store, determined by:

$$
P s_{S M A}=\left(1-S A J^{2}\right) P n
$$

with $S A J$ (dimensionless), the relative level into the reservoir, and $P n_{S M A}(\mathrm{~mm})$, the daily net rainfall, equal to the daily rainfall minus the daily potential evaporation estimate.

Conversely, if the evapotranspiration is greater than the rainfall, then a quantity $E s$ is removed from the store, determined by:

$$
E s_{S M A}=S A J(2-S A J) E n
$$

with $E n(\mathrm{~mm})$ the net evapotranspiration equal to the daily evaporation estimate minus the daily rainfall.

\section{- Generating discharges}

Secondly, elementary discharges are calculated for each pixel with a simple rainfallrunoff model that combines a production store (which is similar to the SMA model), and a routing store (Fig. 2). The production store has a maximal capacity equal to $A$. Its relative level noted $k$ determines the ratio of rainfall, noted $\mathrm{Pr}$, which will pass through the routing store :

$$
\operatorname{Pr}=k^{2} P
$$

The remaining rainfall ( $\mathrm{P}-\mathrm{Pr}$ ) fills the production reservoir. When $\mathrm{k}=1$ (full reservoir), $100 \%$ of the rainfall contributes to the flood.

The routing store is driven by the following equation:

$$
Q r=R^{5} / 4 B^{4}
$$

with $B$, the one-day ahead capacity of the routing store $(\mathrm{mm})$. 
The initial rate of the production reservoir is obtained from the daily humidity index $(S A J)$ of the previous day:

$$
S_{0} / A=a S A J+b
$$

with $a$ and $b$, local values of the initialisation rule.

The rooting reservoir is always initialised at the same level (30\%). If the 24-hr rainfall of the previous day is below $10 \mathrm{~mm}$, both reservoirs are re-initialised.

Finally, discharges are derived at the catchment outlet. In the real-time version of the model for the Mediterranean area, the elementary runoff values from all the catchment grid cells are simply summed, neglecting their travel time to the outlet. This simplification is done to maximize the capacity of the model to anticipate the flood.

The calibration procedure used for determining model parameters is presented in Javelle et al. (2010). A cross validation was carried out on 160 gauged catchments located in the South of France.

\section{- Comparing to reference peak flow quantiles}

Real-time estimated peak discharges are compared to reference peak flow quantiles that have been derived by a flood frequency analysis method called SHYREG (also providing rainfall quantiles as mentioned earlier for the APIC warning system). This method is based on a regionalised stochastic rainfall generator (Arnaud et al, 2008), which is coupled to the rainfall-runoff model used by AIGA in real-time at the $1-\mathrm{km}^{2}$ resolution. The $1-\mathrm{km}^{2}$ gridded estimates of discharges for various durations and return periods are statistically aggregated to produce flood frequency estimates at any point along the river network. The method has been regionalized for the metropolitan France using hydroclimatic and hydrogeological catchment characteristics. SHYREGestimated peak flow quantiles have been validated by Organde et al, (2013) with a cross-validation approach for return periods of two to 10 years.

In real time, to describe the potential severity of the on-going event along the river network, the estimated peak discharges are represented with a colour code based on three flood frequency categories: yellow for peak discharge ranging from the 2year to the 10-year flood, orange from the 10-year to the 50-year flood, and red for peak discharge exceeding the 50-year flood. These real-time products, delivered every 15 minutes, are used as input for a web site dedicated to French local authorities. They are also sent to operational flood forecasting services to enable forecasters to visualize and analyse various model outputs when deciding whether flood warnings should be issued. AIGA may also be re-run on past events for more detailed evaluation studies.

\section{THE JUNE 2010 FLOOD ON THE ARGENS CATCHMENT}

\section{Event description}

The Argens catchment $\left(2700 \mathrm{~km}^{2}\right)$ is located in the South of France (Fig 3). Its altitude ranges from sea level up to $1173 \mathrm{~m}$. The hydrological regime is typical of the Mediterranean climate, with very low flows in summer, and floods occurring mainly in autumn. 
On June $15^{\text {th }}$ and $16^{\text {th }} 2010$, the Argens catchment was affected by torrential rains of an exceptional intensity caused by stationary thunderstorms. Precipitations started on the morning of June $15^{\text {th }}$ and lasted almost 24 hours, with a maximal intensity in the afternoon of the same day. During this 24 hours period, the maximal daily amount (from 6UTC to 6UTC) recorded by the rain gauge located in the most exposed area reached $456 \mathrm{~mm}$ (at Lorgues), with a maximal intensity of almost $80 \mathrm{~mm} / \mathrm{h}$ at $3 \mathrm{pm}$ (local time). Recorded values at all rain gauges in the Argens catchment exceeded by far the highest historically known values (from time series up to 80-year long). The spatial extent of the event was considerable, with, for example, a $100-\mathrm{km}^{2}$ area experiencing at least $300 \mathrm{~mm}$. The return period for such an event is estimated to more than one hundred years.

Figure 4 represents the cumulated rainfall from June $15^{\text {th }} 20106$ UTC to $16^{\text {th }}$ June 2010 6UTC from two sources of data: rain gauges and the real-time radar-gauge products (PANTHERE) from Météo-France. The rainfall spatial repartition shows that rainfall mainly affected the middle of the Argens catchment, and particularly its subcatchments Florieye, Nartuby, Aille and Real (presented in Fig. 2).

Usually, in this area, floods are mainly observed in autumn due to thunderstorms occurring on potentially saturated soils. This June flood was therefore unusual: it occurred in summer when soils were dry due to the combination of weak precipitations and strong evapotranspiration. However the intensity of the rainstorm event was sufficient to produce a very important and rapid response of the affected catchments.

As a result, water levels rose very rapidly and, in urban areas, floodwaters engulfed streets in torrents of mud, swept away cars and trees, and made roads collapse. Rising waters also trapped a high speed train with more than 300 people on board. 25 casualties were reported, a total of 2450 people were evacuated, including 1350 by helicopter (Rouzeau et al, 2010). The French federation of insurance companies reported that 35700 damage claims were declared for a total cost of 615 billion euros. Public network equipment for roads, telecom, and energy were also strongly affected, with a cost estimated at 12.5 billion euros. Most of the damages were caused on the Nartuby River around the town of Draguignan and on the Argens River, downstream the Nartuby, in strongly urbanised areas. The estimated response times of the Nartuby and Argens catchments (at their downstream outlets) are around 6 hours and 24 hours respectively.

\section{Warnings issued during the event}

Figure 5 presents the global situation simulated by the AIGA system at $5.15 \mathrm{pm}$ while table 1 compares the time of issued warnings with the situation observed on the ground. Flooding was first reported around 4pm on the upstream areas: Real River at Les Arcs, Florieye River at Taradeau, and Nartuby River at Rebouillon. For these rivers and at that time, the AIGA system issued level-2 warnings for peak discharges exceeding the 10-year flood. Then, flooding affected the urbanized area of Draguignan at $5 \mathrm{pm}$ and Trans-en-Provence at $5.45 \mathrm{pm}$. At $5.15 \mathrm{pm}$, the whole Nartuby River reached the level-3 warning, indicating that the AIGA-estimated flood peaks exceeded the 50-year return period (Fig. 5).

According to the rescue services, the situation became extremely critical after $5.15 \mathrm{pm}$, with more than 500 demands for rescue, including people being blocked on car or house rooftops and on a bridge. Overall, the AIGA warnings clearly identified the most affected areas. 
Regarding the effective warning lead time, there was almost no anticipation on the Real, the Florieye, and the upstream Nartuby River, due to the short response times of these catchments and the fact that the hydrologic model takes into account only rainfall observations (and no precipitation forecast). However, for the downstream Nartuby River and the Argens River, with longer response times, AIGA offered a significant warning lead time, which helped to organize and coordinate the emergency and rescue operations.

\section{EVALUATION OF SIMULATED DISCHARGES USING POST-EVENT PEAK FLOOD ESTIMATES}

\section{Collected field data}

Five hydrometric stations were in service before the flood event: two on the Nartuby River, one the Aille River, and two on the Argens River. However, only two of them were able to record water levels during the flooding: on the Aille River and on the Argens River, upstream. For both of these two stations, recorded values were well above the maximum gauged level on the rating curve, thus the discharge estimation from these values was considered too uncertain.

Because of this lack of discharge measurements during the flood, the technical services of the French State and local authorities, as well as research institutions involved in the international HyMeX project, jointly conduct an extensive field survey right after the flood (Payrastre et al. 2012). Maximum water levels were determined from high water marks and cross sections were measured. Then flood peak discharges were estimated at multiple sites by different methods. All of these discharge estimation methods contain a certain part of subjectivity and expert considerations, including: flow velocity determined from similar past events, expert-based Strickler coefficient to apply the Manning-Strickler formula, adapted hydraulic formulas with expert-based parameters for specific hydraulic structures (such as contraction parameters for weirs) (see Lumbroso and Gaume 2012 for further discussion of indirect methods). Comparisons of the resulting discharge estimations and discussions among the involved scientists led to a common subset of 16 sites for which 'consolidated' estimates of the flood peak ranges were provided with minimum and maximum 'accepted' values (Table 2).

\section{Evaluation of simulated peak discharges}

Peak flood discharges simulated by AIGA were compared to the consolidated range estimates of flood peaks from the post-event field campaign (Table 2). Figure 5 indicates that AIGA discharges are in good agreement with field estimates for 6 locations: \# 1 (Real), \#5 and \#6 (Nartuby) \#13, \#15 and \#16 (Argens). However, at 5 locations, AIGA seems to overestimate peak discharges: \#2 (Real) and \#7, \#8, \#9, \# 10 (Nartuby), and underestimation is observed at 5 other locations: \#3, \#4 (Florieye) and \#11 (Aille), 12\# and 14\# (Argens).

The differences between field estimates and AIGA results can be explained by errors in the radar QPE but also by AIGA limitations. 
Indeed, Figure 4 shows globally a good agreement between radar estimates and field raingauges, but in the most affected area, radar underestimates the value provided by raingauges: for instance at the raingauge which recorded the highest value $(456 \mathrm{~mm})$, the radar estimated a value around $230 \mathrm{~mm}$. This limited area, with a $50 \%$ rainfall underestimation, concerns essentially the Florieye catchment and a part of the Aille catchment. This gives a possible explanation for the AIGA underestimations observed at Figure 5. The radar underestimation in this area can be explained by the fact that the raingauge indicating the $456 \mathrm{~mm}$ value has not been used in real time for the radar correction step (step 2 in the section presenting the QPE product) since this raingauge does not belongs to real time teletransmitted raingauge network from Meteo France.

Figure 5 also reported some overestimation of the model. This can be explained in some locations by water temporarily stored by bridge cross sections or urbanized areas, having for consequence a decrease of the peak flood downstream. This was the case on the Real river at location \#2 and also on the Nartuby, downstream the flooded city of Draguignan. These were not accounted for by AIGA, which has no specific modelling of such storage processes in urbanised areas. Another explanation for AIGA overestimations lies in the way elementary discharges are transferred to the basin outlet. As explained earlier, the elementary discharges calculated in each cell are simply summed at the basin outlet without any consideration of their travel time in order to maximise the effective warning lead time. However the current simplistic procedure is likely to evolve in the future to produce more realistic hydrographs.

Nonetheless, one should note that, even if there are errors in the magnitude of the peak flow values, warnings are not significantly affected. Indeed, the warning levels are associated with return periods. Real time simulated discharges are compared to statistical peak flow quantiles issued from the same hydrologic model. This provides an implicit correction of the hydrologic biases: comparison of calculated return periods will not be impacted by differences between the modelled flows and observed flows.

\section{CONCLUSIONS AND PERSPECTIVES}

The performance evaluation of the AIGA flash flood warning systems is inherently difficult on ungauged basins due to the lack of hydrometeorological datasets and the small scales of the events. In this paper, the proposed evaluation strategy consists of comparing the issued warnings to reports of the impacts observed on the ground, as well as comparing the modelled peak flow values to estimations from post-event surveys on the ground. For the June 2010 flood, an intensive post-event survey conducted by different teams led to consolidated flood peak ranges at 16 locations.

The evaluation yielded the following results:

AIGA warnings were coherent with the flood impacts observed in the field, even if the effective warning lead time or flood anticipation was limited to downstream catchments with longer response time; despite some differences, flood peak discharges estimated by AIGA are generally coherent with the field-based estimations. 
Differences between AIGA- and field-estimated flood peak values are partly due to the rainfall underestimation in the radar-gauge rainfall grids in some areas Current efforts at Météo-France for improving operational rainfall estimates (with enhanced real-time correction and polarimetric radar for example) show promising results (Tabary et al, 2011). However results also showed some overestimated peak discharges, underlining the need for improving the hydrological model for high flow prediction.

Regarding flash flood warnings, even if the AIGA warning lead time was limited for the June 2010 flood and the flood magnitude not accurately estimated, the warning information was helpful to describe the potential severity of the upcoming and ongoing event. The main reason is that warnings are related to return periods, with discharge thresholds based on simulations. This reduces the bias of the method. According to the emergency and rescue services, the situation reported by AIGA was one of the elements taken into account in the operational decision process when the alert was put at its maximum level and additional rescue resources were required. AIGA provided a 'synthesized' view of the flood situation while only partial and local information emerged from the field, sometimes hindered by communication problems (e.g. lost mobile network).

Future developments related to the AIGA method aim at implementing the method across the entire French territory, in collaboration with the SCHAPI (French national hydro-meteorological and flood forecasting centre). Ongoing research focuses on the model structure enhancements, but also on the use of future rainfall scenarios in order to increase the warning anticipation. Indeed, the actual system is only based on observed QPEs.

The evaluation of flash flood warning systems is required to demonstrate the current performance of such systems, to provide guidance for future improvements, and to better understand the physical processes and societal factors associated with such extreme events. Post-event surveys are critical to develop comprehensive observational datasets for evaluating the warning system performance at ungauged locations. Furthermore, significant and robust evaluation needs to be conducted on a large set of flash flood events from different areas with various hydrometeorological regimes. For this purpose, Irstea is actively collecting ground measurements after significant flood events in the South of France to estimate associated peak flows for ungauged and gauged locations (see for instance Tolsa et al. 2013). As part of the RHYTMME project, evaluation of AIGA is also conducted on ungauged basins both in hindcast mode using a historical database of flood damage reports and in real-time mode using feedback from end-users. Besides, as part of the HyMeX international initiative, the FloodScale project (http://floodscale.irstea.fr/front-pageen?set_language=en) includes the collection of detailed observations from both operational and research hydrometeorological systems as well as from post-event surveys, testing for example the setup of Large Scale Particle Image Velocimetry networks to increase the density of discharge estimations (Le Coz et al 2010, Dramais et al, 2011).

Data collection efforts should also be pursued for information relative to flash flood impacts to better understand the societal vulnerability factors and the dynamic nature of population exposure to fast evolving events (Calianno et al 2013). As emphasized by Gourley et al (2013) and Montanari et al (2013), close collaboration between the scientific community and practitioners involved in monitoring water- 
related observations should facilitate these data acquisition efforts. The general public could also participate, for example by sharing georeferenced photographs and films of flooded areas via social media. Besides, Hrachowitz et al (2013) provided a comprehensive review of advances in sensing technologies, which could potentially be highly valuable for hydrology in poorly and ungauged areas, thanks to increased areal coverage and reduced estimates uncertainty. The authors also insisted on the need for increased data sharing, with freely accessible and unified databases and online information repositories, in order to facilitate collaborative activities. The interdisciplinary approach from hydrology to socio-economic sciences and the direct involvement of the research community along with practitioners and public administrators are one of the promising focuses of the new Panta Rhei science initiative (Montanari et al 2013). Regarding warning systems, social sciences in particular could contribute to more effectively communicate warnings and the uncertainty therein and to better understand the processes of risk-based decision making of a wide range of users, from individuals in small communities to large urban areas.

\section{REFERENCES}

Alfieri, L., Salamon, P., Pappenberger, F., Wetterhall, F., Thielen, J., Operational early warning systems for water-related hazards in Europe, 2012a, Environmental Science \& Policy, 21: 35-49

Alfieri, L., Thielen, J. and Pappenberger, F., 2012b. Ensemble hydro-meteorological simulation for flash flood early detection in southern Switzerland. Journal of hydrology, 424 425(1): 143-153.

Arnaud, P., Lavabre, J., Sol B., Desouches, Ch., 2008. Régionalisation d'un générateur de pluies horaires sur la France métropolitaine pour la connaissance de l'aléa pluviographique. Hydrological Sciences Journal, 53(1): 34-46.

Bartholmes, J.C., Thielen, J., Ramos, M.H. and Gentilini, S., 2009. The european flood alert system EFAS : Part 2: Statistical skill assessment of probabilistic and deterministic operational forecasts. Hydrology and Earth System Sciences, 13(2): 141-153.

Borga, M., Boscolo, P., Zanon, F. and Sangati, M., 2007. Hydrometeorological Analysis of the 29 August 2003 Flash Flood in the Eastern Italian Alps. Journal of Hydrometeorology, 8(5): 1049-1067.

Calianno, M., Ruin, I. and Gourley, J.J., 2013. Supplementing flash flood reports with impact classifications. Journal of Hydrology, 477(0): 1-16.

Carrière, J-M., Brovelli, P., Tzanos, R., 2013 : APIC : service d'avertissement de pluie intense, Météo - le magazine, 14, 18-19.

Champeau, J.-L., Vogt, V. and Tabary, P., 2012. The French radar conventional Quantitative Precipitation Estimation : present and future, 7th European Conference on Radar in Meteorology and Hydrology (ERAD), Toulouse, France, 24-29 June 2012.

Cole S. and Moore R., 2009. Distributed hydrological modelling using weather radar in gauged and ungauged basins, Advances in Water Resources, 32: 11071120 .

Creutin, J.D. and Borga, M., 2003. Radar hydrology modifies the monitoring of flashflood hazard. Hydrological Processes, 17(7): 1453-1456. 
Dramais, G., Le Coz, J., Camenen, B. and Hauet, A., 2011. Advantages of a mobile LSPIV method for measuring flood discharges and improving stage-discharge curves. Journal of Hydro-environment Research, 5(4): 301-312.

Emmanuel, I., Andrieu, H. and Tabary, P., 2012. Evaluation of the new French operational weather radar product for the field of urban hydrology. Atmospheric Research, 103(103): 20-32.

Fouchier, C., 2010. Développement d'une méthodologie pour la connaissance régionale des crues, Université Montpellier II, Sciences et techniques du Languedoc, $266 \mathrm{pp}$.

Gaume, E. et al., 2009. A compilation of data on European flash floods. Journal of Hydrology, 367(1-2): 70-78.

Georgakakos, K.P., 2006. Analytical results for operational flash flood guidance. Journal of Hydrology, 317(1-2): 81-103.

Gourley, J.J., Erlingis, J.M., Hong, Y. and Wells, E.B., 2012. Evaluation of Tools Used for Monitoring and Forecasting Flash Floods in the United States. Weather and Forecasting, 27(1): 158-173.

Gourley, J.J., Erlingis, J.M., Smith, T.M., Ortega, K.L. and Hong, Y., 2010. Remote collection and analysis of witness reports on flash floods. Journal of hydrology, 394(1): 53-62.

Gourley J-J., Hong Y., Flamig Z., Arthur A., Clark R., Calianno M., Ruin I., Ortel T., Wieczorek M., Kirstetter P-E., Clark E., and Krajewski W., A Unified Flash Flood Database across the United States, 2013. Bull. Amer. Meteor. Soc., June 2013, 799-805.

Hapuarachchi, H.A.P., Wang, Q.J. and Pagano, T.C., 2011. A review of advances in flash flood forecasting. Hydrological Processes, 25(18): 2771-2784.

Hrachowitz, M., et al, 2013. A decade of Predictions in Ungauged Basins (PUB) - a review, Hydrological Sciences Journal, 58:6, 1198-1255, DOI: 10.1080/02626667.2013.803183

Javelle, P., Fouchier, C., Arnaud, P. and Lavabre, J., 2010. Flash flood warning at ungauged locations using radar rainfall and antecedent soil moisture estimations. Journal of Hydrology, 394(1-2): 267-274.

Le Coz, J., Hauet, A., Pierrefeu, G., Dramais, G. and Camenen, B., 2010. Performance of image-based velocimetry (LSPIV) applied to flash-flood discharge measurements in Mediterranean rivers. Journal of Hydrology, 394(1-2): 42-52.

Lefort, P., Koulinski, V., 2011. Crue du 15-16 juin 2010: Expertise post-crue, Tome 1, Analyse hydrologique de la crue de juin 2010. Conseil Général du Var, Direction de l'Environnement, Service Rivière et Milieux Aquatiques, Syndicat intercommunal d'Aménagement de la Nartuby: 33.

Lumbroso, D. and Gaume, E., 2012. Reducing the uncertainty in indirect estimates of extreme flash flood discharges. Journal of Hydrology, 414-415: 16-30.

Montanari, A., et al, 2013. "Panta Rhei-Everything Flows": Change in hydrology and society-The IAHS Scientific Decade 2013-2022, Hydrological Sciences Journal, 58:6, 1256-1275, DOI:10.1080/02626667.2013.809088

Organde, D. et al., 2013. Régionalisation d'une méthode de prédétermination de crue sur l'ensemble du territoire français : la méthode SHYREG. Revue des sciences de l'eau, 26(1): 65-78.

Ortega, L. et al., 2009. The Severe Hazards Analysis and Verification Experiment. Bulletin of the American Meteorological Society, 90(10): 1519-1530. 
Payrastre O., G., Javelle P., Janet B., Fourmigué P., Boudevillain B., Lefort Ph., Marchi L., Delrieu G., Brunet P., Martin C. , Ruin I., Boissier L. , Douvinet J. , Lang M. , Aubert Y., 2012. Analyse hydrologique de la catastrophe du 15 juin 2010 dans la région de Draguignan (Var, France), Colloque pour le centenaire de la Société Hydrautechnique de France « Evénements extrêmes fluviaux et maritimes. Leurs variabilités spatiales et chronologiques dans l'ouest de l'Europe », 1-2 Feb. 2012, Paris.

Perrin, C., Michel, C. and Andréassian, V., 2003. Improvement of a parsimonious model for streamflow simulation. Journal of Hydrology, 279(1-4): 275-289.

Ramos, M.H., Bartholmes, J. and Thielen-del Pozo, J., 2007. Development of decision support products based on ensemble forecasts in the European flood alert system. Atmospheric Science Letters, 8(4): 113-119.

Reed, S., Schaake, J. and Zhang, Z., 2007. A distributed hydrologic model and threshold frequency-based method for flash flood forecasting at ungauged locations. Journal of Hydrology, 337(3-4): 402-420.

Rouzeau, P., Martin, X., Pauc, J-C., 2010. Retour d'expérience des inondations survenues dans le département du Var les 15 et 16 juin 2010, Inspection générale de l'administration, Ministère de l'écologie, de l'energie, du développement durable et de la mer, Ministère de l'intérieur, de l'outre mer et des collectivités territoriales.

Ruin, I., Creutin, J.D., Anquetin, S. and Lutoff, C., 2008. Human exposure to flash floods - Relation between flood parameters and human vulnerability during a storm of September 2002 in Southern France. Journal of Hydrology, 361(1-2): 199-213.

Tabary, P., 2007. The New French operational radar rainfall product. Part I: Methodology. Weather and Forecasting, 22(3): 393-408.

Tabary, P. et al., 2011. Evaluation of two integrated polarimetric Quantitative Precipitation Estimation (QPE) algorithms at C-band. Journal of Hydrology, 405(3-4): 248-260.

Thielen, J., Bartholmes, J., Ramos, M.H. and De Roo, A., 2009. The European flood alert system - part 1: Concept and development. Hydrology and Earth System Sciences, 13(2): 125-140.

Tolsa M., Aubert Y., Le Coz J., Renard B., Arnaud P., Fine J.-A., Organde D. (2013) Méthode de consolidation des courbes de tarage pour les crues d'occurrence rare sur le bassin expérimental du Réal Collobrier, Consolidation method for rating curves in case of rare floods in the Réal Collobrier experimental watershed. Conference proceedings of Hydrometry 2013, Measurements and uncertainties, Paris, 15-16 May 2013.

Younis, J., Anquetin, S. and Thielen, J., 2008. The benefit of high-resolution operational weather forecasts for flash flood warning. Hydrology and Earth System Sciences, 12(4): 1039-1051. 

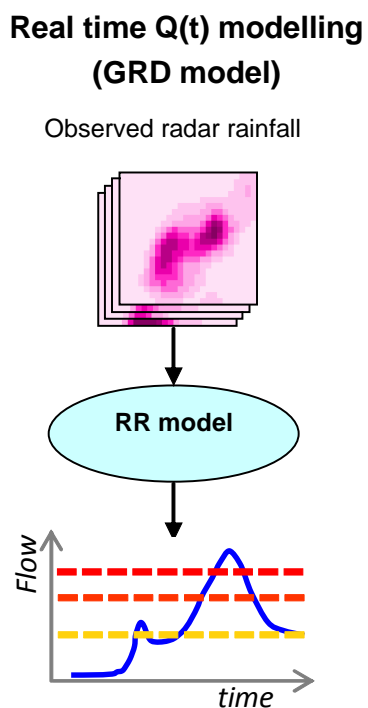

Flood warnings

(AIGA)
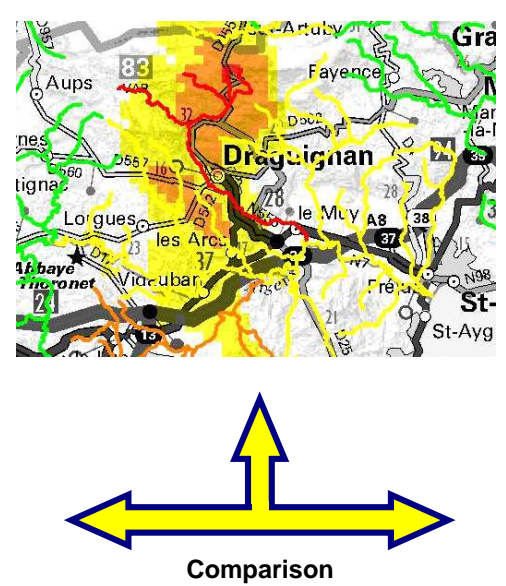

Reference flood quantiles (SHYREG)

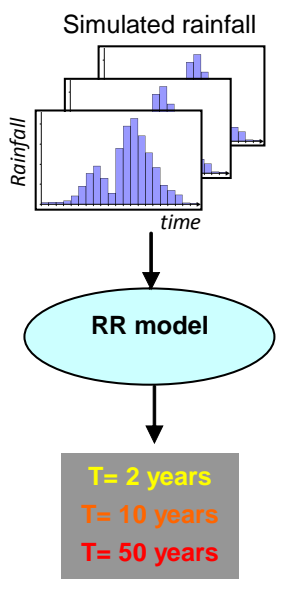

Figure 1: Schematic of the AIGA flash flood warning system and information flow (adapted from Fouchier, 2010)

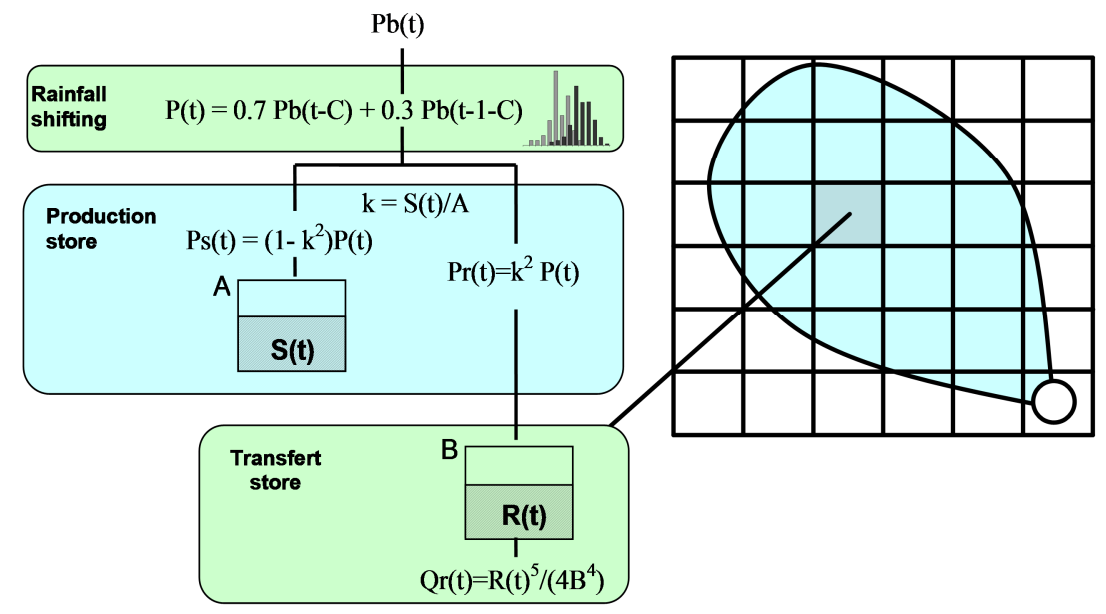

Figure 2: Discharges generation in each elementary cell 


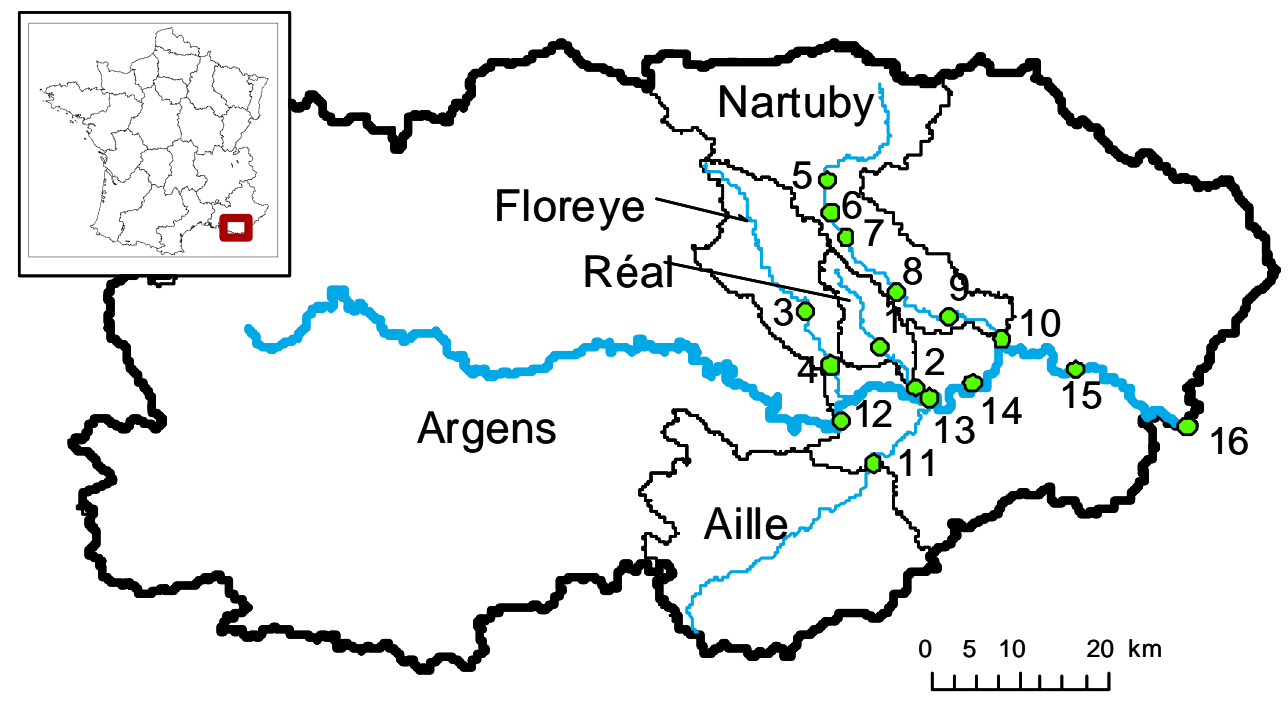

Figure 3: Localisation of the Argens catchment and its main tributaries

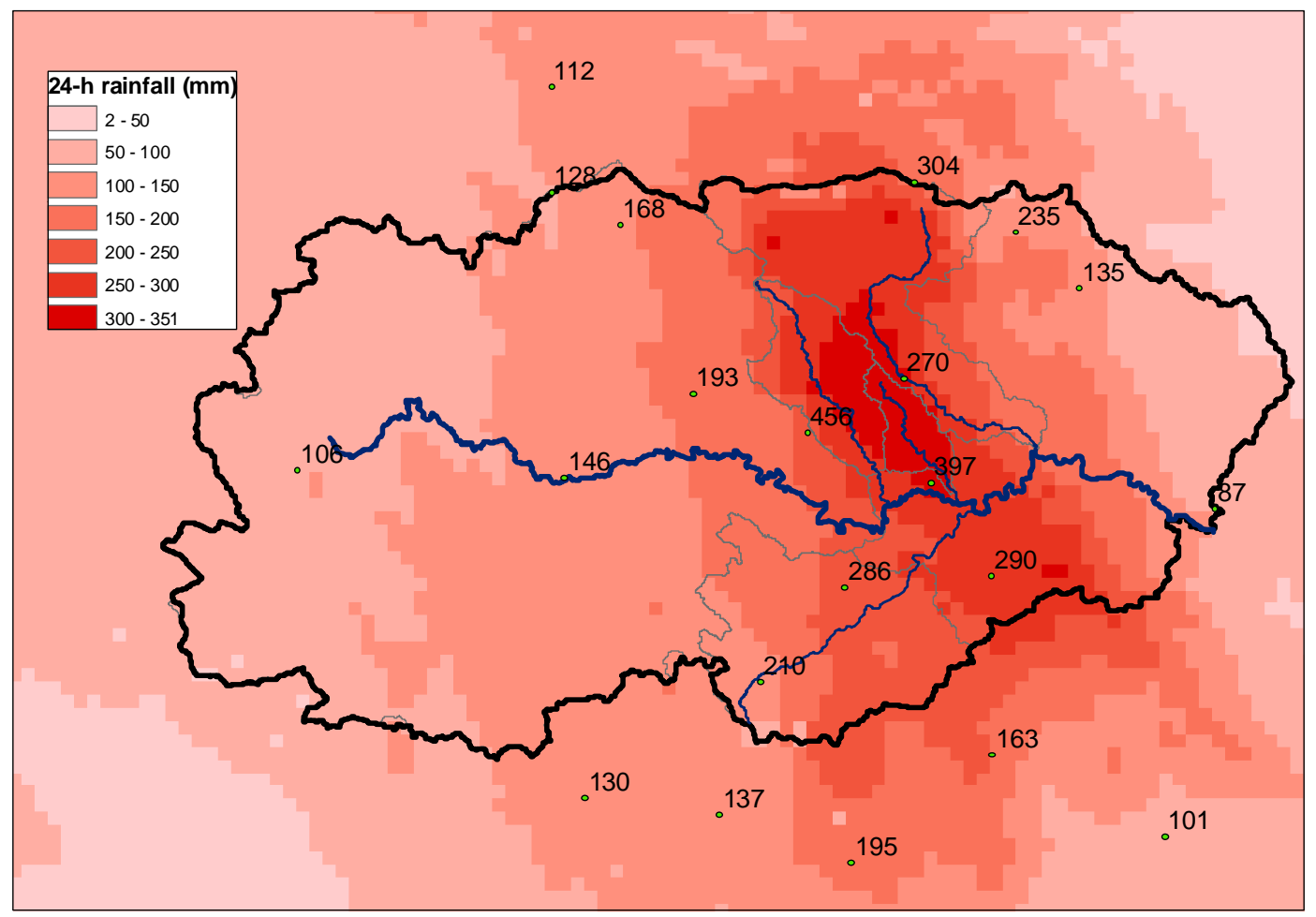

Figure 4: Cumulated rainfall from 15 June 2010 6UTC to 16 June 2010 6UTC given by rain gauges and radar-gauge PANTHERE product from Météo-France 


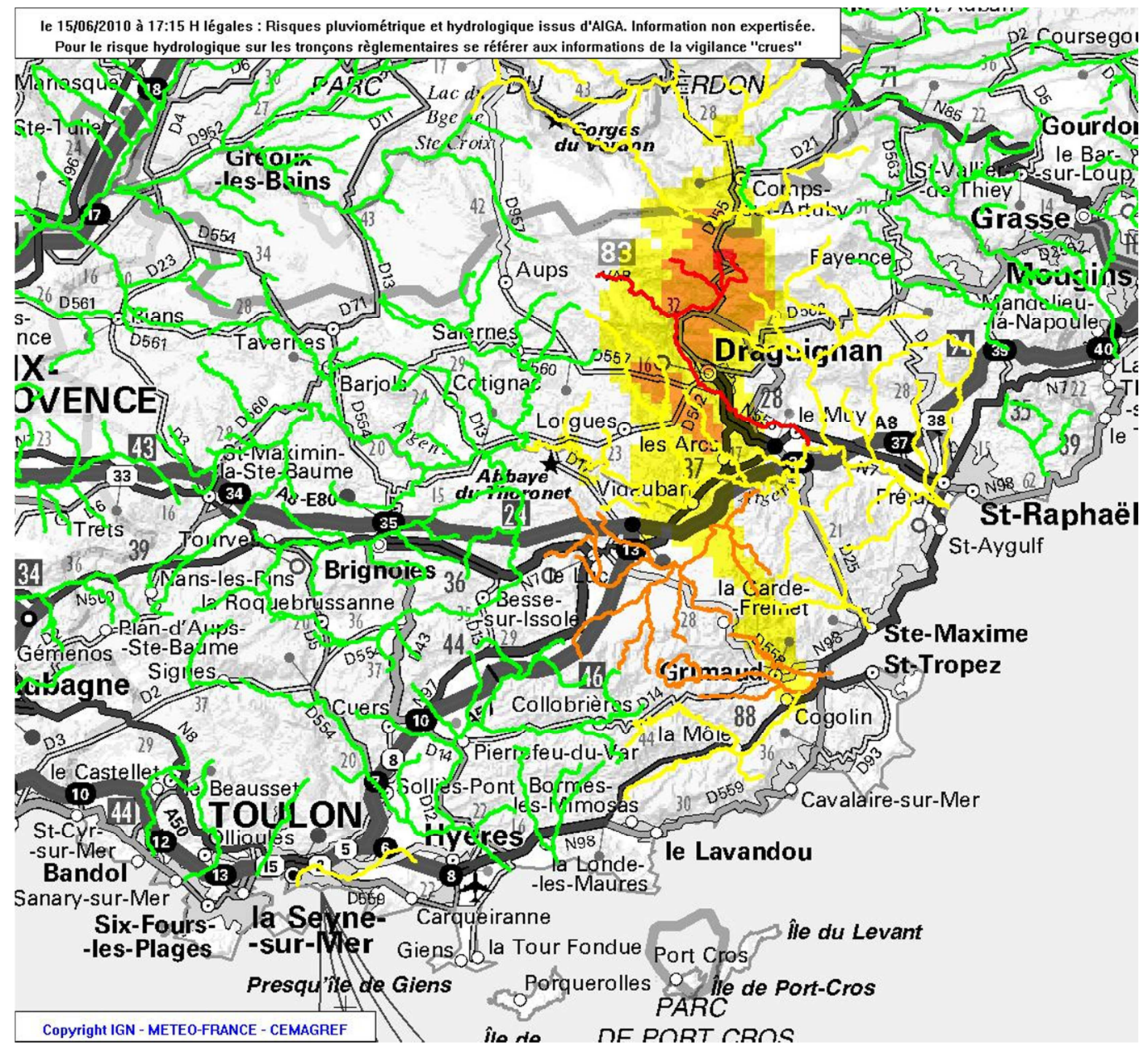

Figure 5: AIGA situation at 5.15pm (local time), when the town of Draguignan was flooded: green ( $T<2$ years), yellow ( 2 years $<T<10$ years), orange $(10<T<50$ years) and red $(\mathrm{T}>50$ years $)$ 


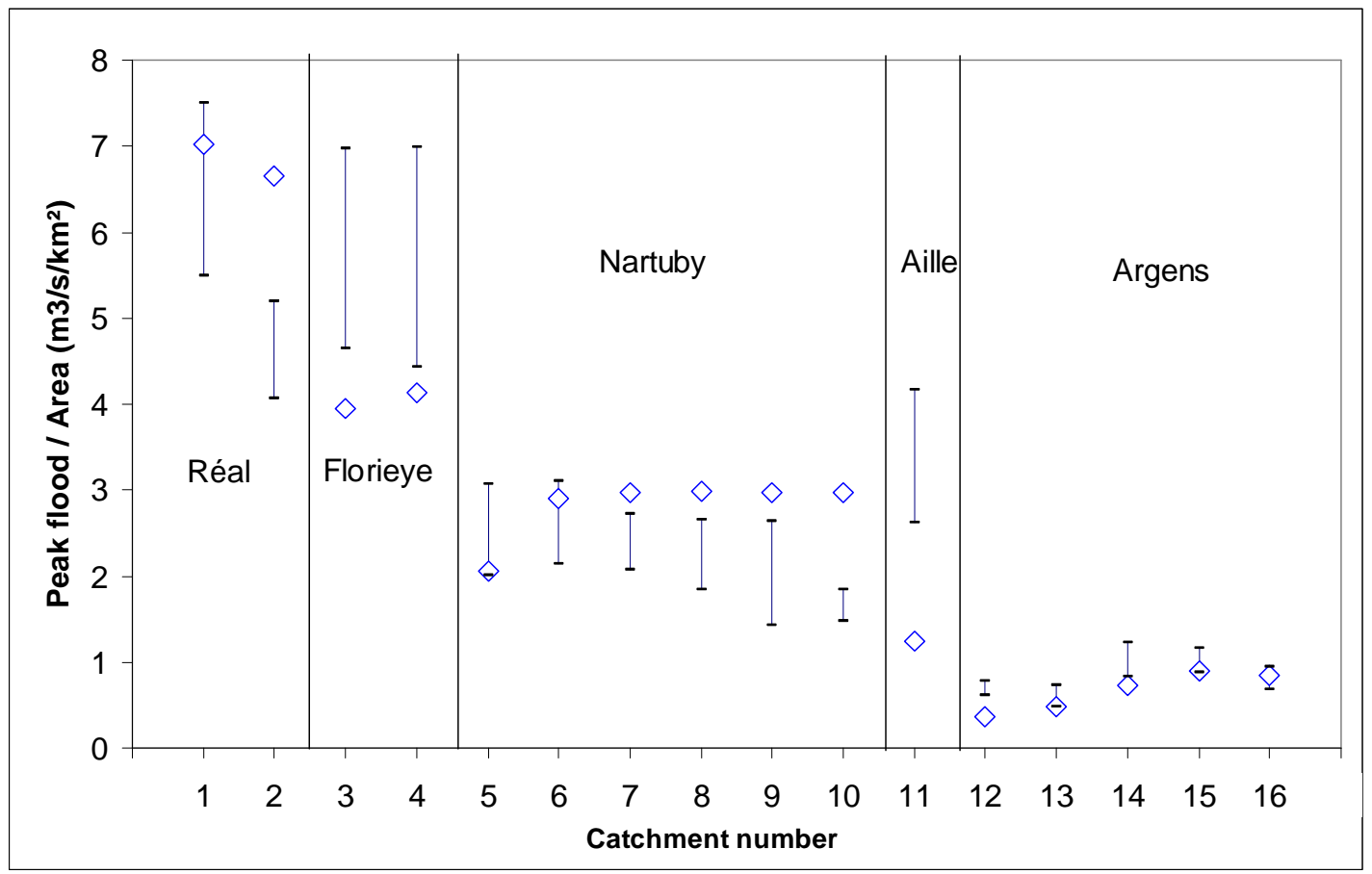

Figure 6: comparison of AIGA-estimated flood peaks (plotted as diamonds) and fieldestimated consolidated flood peak ranges (plotted as bars) 
Table 1: Timing of the AIGA warnings compared to observed damages (in local time)

\begin{tabular}{|l|l|l|l|l|l|l|}
\hline \multirow{2}{*}{ R } & \multirow{2}{*}{ River } & Sector & \multicolumn{3}{|c|}{ AIGA Warning Time } & $\begin{array}{l}\text { Observed damages } \\
\text { (source Lefort and Koulinski, 2011) }\end{array}$ \\
\cline { 4 - 6 } & & & $\begin{array}{l}\text { Level 1 } \\
\text { (T>2 years) }\end{array}$ & $\begin{array}{l}\text { Level 2 } \\
\text { (T>10 years) }\end{array}$ & $\begin{array}{l}\text { Level 3 } \\
\text { (T>50 years) }\end{array}$ & \\
\hline 1 & Real & Les Arcs & $15: 00$ & $16: 00$ & $19: 00$ & $\begin{array}{l}16: 10: \text { Flooding in village } \\
16: 40 \text { Collapse of main centre place (under which } \\
\text { river was canalised) }\end{array}$ \\
\hline 3 & Florieye & Taradeau & $15: 15$ & $16: 15$ & $17: 30$ & $\begin{array}{l}16: 00: \text { Bridge by-passed by the river (road access } \\
\text { completely destroyed) }\end{array}$ \\
\hline 5 & Nartuby & Rebouillon & $15: 30$ & $16: 15$ & $17: 00$ & $16: 00:$ Bridge over-flooded \\
\hline 6 & Nartuby & Draguignan & $15: 30$ & $16: 15$ & $17: 15$ & $17: 00:$ Flooding in town \\
\hline 8 & Nartuby & Trans-en-P & $15: 30$ & $16: 15$ & $17: 15$ & $17: 45:$ Flooding in town \\
\hline 11 & Aille & Vidauban & $15: 15$ & $17: 00$ & & No damages observed (less urbanised area) \\
\hline 14 & Argens & Le Muy - A8 & $15: 15$ & $16: 45$ & & $20: 30:$ Highway flooded \\
\hline 15 & Argens & Roquebrune & $15: 45$ & $17: 15$ & & $\begin{array}{c}22: 00: \text { Twenty persons blocked on the bridge } \\
0: 15: \text { Flooding in village }\end{array}$ \\
\hline 16 & Argens & Fréjus & $15: 45$ & $17: 15$ & & $\begin{array}{c}3: 15 \text { Flooding in town (including campsites, which } \\
\text { had been evacuated) }\end{array}$ \\
\hline
\end{tabular}

Table 2: Consolidated range estimates of the peak flood discharges on 16 locations from post-event field campaign

\begin{tabular}{|c|c|c|c|c|c|}
\hline \# & River & Name & $\begin{array}{l}\text { Area } \\
\text { km }^{2}\end{array}$ & $\begin{array}{l}\text { Qmin } \\
\mathbf{m}^{3} / \mathrm{s}\end{array}$ & $\begin{array}{l}\text { Qmax } \\
\mathbf{m}^{3} / \mathbf{s}\end{array}$ \\
\hline 1 & Real & LesArcs - RD57 upstream village & 20 & 65 & 140 \\
\hline 2 & & Les Arcs - Train bridge & 30,8 & 125 & 160 \\
\hline 3 & Florieye & Lorgues - RD562 & 64,6 & 300 & 450 \\
\hline 4 & & Taradeau - Canyon exit & 85,8 & 380 & 600 \\
\hline 5 & Nartuby & Rebouillon & 149,5 & 300 & 460 \\
\hline 6 & & Draguignan - La Clappe & 164 & 350 & 510 \\
\hline 7 & & Draguignan - Pont d'Aups & 169 & 350 & 460 \\
\hline 8 & & Trans-en-Provence & 195,8 & 360 & 520 \\
\hline 9 & & Capellan & 209 & 300 & 550 \\
\hline 10 & & Le Muy - RN7 bridge CD25 & 229 & 340 & 420 \\
\hline 11 & Aille & Vidauban & 228,3 & 600 & 950 \\
\hline 12 & Argens & Vidauban - RD 48 & 1550 & 950 & 1200 \\
\hline 13 & & Les Arcs & 1654 & 800 & 1200 \\
\hline 14 & & Le Muy - A8 & 2047 & 1700 & 2500 \\
\hline 15 & & Roquebrune & 2491 & 2200 & 2900 \\
\hline 16 & & Fréjus - Saint Aygulf & 2661 & 1820 & 2500 \\
\hline
\end{tabular}

